\title{
Globalization and Development Trends of Vietnam's Civil Law
}

\author{
Duong Quynh Hoa ${ }^{1}$ \\ ${ }^{1}$ Institute of State and Law, Vietnam Academy of Social Science, Hanoi, Vietnam \\ Correspondence: Duong Quynh Hoa, Institute of State and Law, Ngo Thi Nham, Hai Ba Trung District, Hanoi, \\ Vietnam. Tel: 84-43-978-4637. E-mail: dqhoa77@gmail.com
}

Received: April 12, 2017

doi:10.5539/ilr.v6n1p145
Accepted: May 3, $2017 \quad$ Online Published: October 30, 2017

URL: https://doi.org/10.5539/ilr.v6n1p145

\begin{abstract}
This article studies the development trends of Vietnam civil law in the globalization context. We focus on civil law, globalization and current development trends of Vietnam civil law. The interview results on 12 civil law experts indicated the current situation of Vietnam's civil law and its development trends. The law tends to develop with the combination of nationality, internationalization, and self-development. The interview results showed some considerable achievements of the current Vietnam civil law in promoting and protecting the legitimate rights and benefits of individuals, organizations, the State and community. However, the experts still believed that the amendment and supplement of civil law is very essential in the globalization context. Hence, the article proposes five recommendations for improving Vietnam's civil law in the internationalization process.
\end{abstract}

Keywords: globalization, development trend, law, civil law, Vietnam

\section{Introduction}

Civil law in general and Civil Code in particular plays a major role in Vietnam's legal system. Laws that govern the different aspects of private legal relations (e.g. laws on land, credit, business, intellectual property...) are all developed based on the general principles of civil law. Civil Code has shown Vietnam Government's the most main points of view in governing private legal relations. At the same time, civil law makes an important contribution to providing the principles for civil relations as well as the rules for governing the civil relations that are derived.

In general, Civil Code has positive impacts on the socio-economic development in general and legal environment in particular by concretizing the great majority of social relations on the basis of equality, voluntariness and self-responsibility among the subjects. Also, Civil Code minimizes the State's intervention in civil relations. Hence, civil Code promotes and protects the legitimate rights and benefits of individuals, organizations, the State and community.

Despite its important role in the Vietnam legal system, as assessed by some legal experts, the Civil Code still fails to fully actualize its role as a basic code. The above limits and deficiencies themselves greatly impact the effectiveness of the Civil Code due to the fact that a favorable legal environment for the country's socio-economic development and assurance of individuals' rights has not actually established.

The globalization and international integration requires the countries' renovation in many aspects, including the legal sphere for meeting the international requirements. Accordingly, the legal system in general and civil law in particular should be renovated towards the international standards. In the context of the globalization process, Vietnam promulgated the 2015 Civil Code, with the explicit, specific regulations based on the inheritance of the achievements of the 1995 and 2005 Civil Code.

For the above reasons, we selected the subject on "Globalization and development trends of Vietnam's civil law" as the topic of the research. The article focuses on the theoretical framework of civil law, globalization and civil law development trends. In addition, we concentrate on studying Vietnam's civil law development history, the current situation, and the development trends of Vietnam's civil law in the internationalization process, hence proposing recommendations for improving Vietnam's civil law in the context of the internationalization.

\section{Theoretical Framework}

\section{* Overview of civil law}

According to a Latin conception, civil law embraces the general behavioral norms that govern human relations. 
In the Middle Ages, civil law, called "Roman Law", governed all principles in human life and was applied to Roman citizens only. In recent years, civil law attracts more research attention and has been more clearly defined. Raff (2015)'s the findings are prominent. He believes that civil law is a combination of legal norms that govern the property relations and some non-property relations incurred in the processes of goods manufacturing, distribution and circulation. It is based on equality and self-determination of the subjects when they are involved in such relations. According to the 2015 Civil Code of Vietnam, civil law stipulates legal status, legal standards with respect to behavior of individuals; the rights and obligations concerning personal and property relations established on the basis of equality, freedom of will, independence of property and self-responsibility (civil relations).

According to Wright (2015), in the world, common law and civil law are the two typical legal traditions with their own features. Up to now, the laws of the countries belonging to those traditions have changed by supplementing to the limitations and integrating with numerous new contents. The civil law system based on the Roman Law has been the largest legal system in the world and has developed most drastically in France, Germany and some other European countries currently. The civil law systems of these countries are generally under the influence of the Roman Law where substantive law seems to be more important than procedural law and private law is attached with the most importance. The influence of the civil law is significantly wide, including European countries (France, Germany, Italy, etc.), State of Quebec (Canada), Louisiana (USA), Japan and some Latin American countries.

Nguyen Minh Tuan (2007) categorized the civil law in the world into three different groups as follows:

o Civil law of France: in France, Spain, and the former French colonies;

o Civil law of Germany: in Germany, Austria, Switzerland, Greece, Japan, South Korea, and Republic of China;

o Civil law of Scandinavian countries: Denmark, Sweden, Finland, Norway, and Ireland. The civil laws of Portugal and Italy are also under the influence of France and Germany. But, the civil codes in the 19th century were closer to the Napoleon Code, and the civil codes in the 20th century were similar to the civil law of Germany. With respect to legal training, these countries resemble the legal system of Germany more than others. Laws in these countries are often known as legal systems in hybrid nature. The law or civil law in the Netherlands can hardly be grouped into any category. However, it must be accepted that this civil law has the great influence on the modern private laws of many countries. Typically, the current civil law of Russia is under the direct influence of the Netherlands' the law (Caenegem, 1996).

\section{* Globalization and civil law}

The term of "globalization" appeared for the first time in 1961 and has been widely used since the 1980s. Globalization, basically, is a process of increasing dramatically interactions among the countries in the world. Formerly, there were very few relationships among countries. The production development and the increase in goods exchange have gradually developed international relations; hence, the globalization process has started (Chatterjee, 2016). Martens et al. (2010) suggested that social relations always change in the globalization process; this context requires the civil law's change because it governs social relations. So, the civil law's improvement in the globalization tendency is very necessary.

On the whole, the civil law in the globalization process focuses on protecting the rights and benefits of the domestic individuals and organizations for promoting the domestic economic development by encouraging business activities. Additionally, the civil law, over the world, in the recent years, concentrates on individuals and organizations' the moral standards and social responsibilities (Martens et al., 2010).

With its important role as a cornerstone in the legal system, civil law has become a principle law for other laws, such as: Commerce law, Enterprise law, Housing law, Law on Real Estate Business, Intellectual Property Law, Technology Transfer Law, Tendering Law ... (Hoang Thu, 2014). Legal issues arising in the integration process require the emergence of legal works marked by the acquisitiveness of the international practices. This makes a positive contribution to the international economic integration in an ever deeper and more comprehensive manner.

In Vietnam, there have been three civil codes, including: the 1995 Civil Code, the 2005 Civil Code, and the 2015 Civil Code since 1995. Thus, the lifetime of Vietnam's Civil Code is 10 years on average. After of each ten-year period of enforcement, facing new demands arisen from the development and defense of country many provisions of the Code appear to be inadequate for the needs of the social life. One of other objective reasons cause for such a modest lifetime of Vietnam's Civil Codes is the rapid economic development and the deep and 
extensive international integration process as well. In the trends towards the integration and development, Vietnam's civil law changes according to the general legal systems of other countries is essential (Ha Hung Cuong, 2016).

\section{* Civil law's development trends}

Law plays an important role in the integration process due to the increasing interaction and inter-independence among countries in numerous spheres currently. Hoang Thu (2014) said that civil law system becomes more comprehensive if it is based on the need to expand the area of legal development among countries. The international civil law has a close connection with national civil laws, to some certain extent, depends on the common points in national civil laws. Hence, the international civil law is considered as a legal standard for national legal systems.

As assumed by Faunce (2012), the process of legal integration, as well as the social one, has posed a requirement for updating and changing the law, including civil law. The general civil law development trend in the world now is to combine the national, international, and self-development factors altogether.

The current political, economic and cultural life in the world is diversified and complicated. Besides, the civil law can enter into the modern social life in an easier way to represent social values, govern human behaviors, guarantee the stability of civil relations and become means of conducting social reforms and renovation. National civil laws are characterized by countries' own typical features, including institutional type (Chang and Nathan, 2013).

According to Faunce (2012), the development of civil legal documents takes place in a changeable social environment. Also, it is under the influence of the renovation. In addition, the civil law's development trends in the world are affected by the changes in the economy, the state management, social conscience, and human behaviors. The economic renovation determines the civil law's updates and changes. According to historical materialism, the decisive factors those impact the world civil law development trends are infrastructure and production relationships.

Basically, civil law systems are ever changing and being updated to meet the need for co-operation in the legal domain in the tendency towards stability, inheritance and development of the law under the influence of economic, political, social, ideological, geographical, and anthropological factors. It is the combination of such laws that permits countries in the world to balance and find common grounds in the ways of approaching civil law systems (Martens et al., 2010).

In the globalization process, with the social changes and dynamic human life, co-operation in civil law allows countries to further enrich the cultures of the ethnic groups and citizens. Civil law thoughts and normative documents enable population communities to overcome limits easily and bring countries closer together. According to Martens et al. (2010), politicians, managers, and legal researchers in recent times have increasingly attached importance to the general development process of civil law in the world. Analyzing in an objective manner civil law processes and development trends lays foundation for assessing correctly the level of combining common grounds and specific grounds in the political, economic, scientific-technological, and socio-cultural development of countries.

In a general way, as Chen (2008) observed, civil laws comply with the three certain principles, namely:

(i) Promoting international community's common norms;

(ii) Giving higher priorities to generally-accepted international law principles and norms over domestic legal provisions;

(iii) Assuring internationally legal protection of human and citizen the rights and freedoms.

After the II World War, the principle of protection of human and citizen rights and freedoms has been widespreadingly disseminated. The general acknowledgement by the world community helped this to become a basic principle to the civil laws of countries. All civil law normative documents, particular decisions and actions in countries are formulated and carried out on the basis of this principle.

At the present time, the civil law inheritance has become a general tendency in the process of the legal development. According to Andrea and Markus (2012), general development trends of civil law can be categorized into five following groups:

The first group: Developing in compliance with the civil law values that have generally been acknowledged;

The second group: Developing within the domain of civil law with world outlook and general legal resources; 
The third group: Developing in the manner of coordinating closely among the countries allied;

The fourth group: Cooperating in civil law of countries in the region;

The fifth group: Developing in a localized manner. The difference in civil law among countries includes sustainable difference and temporary one. Accordingly, temporary difference tends to be remedied according to political, economic, social environment and some other requirements.

All of the civil law's development trends above take place at different paces with interaction with each other. In the development process, each country is inclined to accumulate, protect, and enrich their typical civil law points of view and institutions. Besides, countries attach special importance to their own national legal typical features by creating favorable conditions for international co-operation. This enables countries to define correctly and objectively the level of differentiation in terms of law and the common interests that are being changed in the sphere of civil law. From the points of view on common interests, countries are aiming at reducing the differences in civil laws and finding out methods to gradually overcome such differences (Chen, 2008).

\section{Methodology}

In this research, firstly, we made a literature review from the different sources of secondary data, such as: academic articles, legal normative documents, reports, research projects relating to civil law and civil law's development. We also referred to the domestic and international researches on globalization and civil law development trends. Through the data collected, we gave an overview of civil laws; globalization and civil law; and civil law development trends. Furthermore, we collected the legal documents governing civil law relations in Vietnam and highlighted the new points of Vietnam's the current civil law.

Secondly, we collected primary data by interviews. We interviewed 12 Vietnamese lawyers and experts about the globalization process and civil law development trends. The primary data collected by interviewing the experts provide the specific demonstrations of the subject. On that basis, we proposed some recommendations for improving Vietnam's civil law in the current context of the globalization.

\section{Research Results}

\section{* History of Vietnam's civil law development}

According to Nguyen Ngoc Dien (2016), Vietnam's civil law development process can be divided into three periods, namely: (i) ancient law period, (ii) sub-modern law period, and (iii) modern period. Up to now, civil law has been improved by promulgating the 2015 Civil Code which defines the principles establishing the spirit of Vietnam's modern civil law toward the perfection of civil law jurisprudence.

In the ancient law period, the concept of civil law was non-existent; the written principles governing individual relationships in ancient society were usually included in the chapters about criminal, administrative matters related to marriages, families, and cultivated land. Phan Huy Chu (1961) was quoted as saying when he assessed the law during the Le dynasty "what an example for governing the country, the rule for bringing the people under", and accordingly, civil law was formed and improved with special care. The "Quốc triều hình luật" (dynasty criminal law) which was archived till today was supplemented by the kings of the last reign of the Le Dynasty and promulgated in 1777 (the 38th year of Canh Hung). The "Quốc triều hình luật" consists of six volumes, 722 articles, and two chapters (Hộ hôn in 58 articles, and Điền sản in 32 articles) and the new additional Điền sản (in 14 articles) dictating the main civil relations at that time such as marriages, families and cultivated land. "Quốc triều hình luật" care for and protects the basic human rights despite being limited by the concept of class (Institute of Historical Studies, 1991). Furthermore, other regulations on civil law relations can be seen here and there in the remaining chapters and in the separate legal documents. The Chairman of Eastern Asia Law Faculty, Harvard University, Prof. Oliver Oldman, greatly appreciated the efforts made in building a strong national state and the protection of the legitimate ownership rights by the progressive legal system of Vietnam under the Le dynasty. Till the Nguyen dynasty, "Hoàng Việt luật lệ" was developed on the basis of the Hồng Đức Code (via Quốc triều Hình luật, the code of the Le dynasty), but chiefly with borrowings from the code of the Ch'ing dynasty, though adapted and updated to conform to the specific conditions of Vietnam at that time (Nguyen Quoc Thang, 2002).

In the sub-modern law period, Vietnam's civil law was developed in the French style with adaptation to conform to the socioeconomic background of Vietnam. Some noticeable written laws at that time included summarized civil law (dân luật giản yếu) (1883), applicable to the South; Decree dated 21/7/1925 on land regime, applicable to the South; the Northern Civil Code (1931); the Central Civil Codes (1936, 1938, 1939); Decree dated 21/2/1921 on trade, applicable to the North and South; Central Commercial Law (1942) ... The written laws as such only recognized the norms marked by principle and complemented by the solutions drawn up in legal 
theories and precedents. Additionally, customs constituted an important source in this period, especially in the South.

In the modern law period, civil law has paid attention by the lawmakers over the last 10 years. Under the Decree No. 47 dated 10/10/1945, during the first years since the foundation of the Vietnam Democratic Republic, the former legal status was still retained except for the provisions against Vietnam's independence and the republican regime. In this orientation, nearly all the civil law (luật hộ) system formed in the colonial period was still remained intact. By 1950, Vietnam set up its socialist civil law system by promulgating the Decree No. 97 dated 22/5/1950 on amending some regulations and institutions in the civil law. The Decree recognized a number of key principles related to personality and property.

Since 1987, the asset relations in the community have become more diversified. A series of civil law norms were developed by the Vietnam State, such as the 1986 Law on Marriage and Family; the 1987 Land Law; the 1987 Law on Foreign Investment in Vietnam; the 1989 Ordinance on Economic Contracts; the 1990 Ordinance on Inheritance; the 1991 Ordinance on Housing and Ordinance on Civil Contracts; the 1993 Land Law; the 1994 Ordinance on Copyright Protection ... The appearance of the legal documents as mentioned above, along with the predictions about the development of civil relations in Vietnam, laid foundation for the improvement of the project on Vietnam's Civil Code, adopted by the National Assembly on October 28, 1995 and came into effect as from June 1, 1996. The 1995 Civil Code was rated as the greatest achievement of the fifty years' development of the contemporary civil law system of Vietnam. However, the promulgated 1995 Civil Code enacted failed to become the basic foundation for private laws in Vietnam due to its deficiencies and its limited contribution to promote civil life (Nguyen Ngoc Dien, 2016).

On June 14, 2005, the National Assembly passed the 2005 Civil Code (in effect assume January 01, 2006), proceeding from the inheritance of the basic principles and contents of the 1995 Civil Code. The 2005 Civil Code displayed more expressly the principle of respecting self-agreement and self-responsibility among the subjects in civil relations by reducing the State's administrative interventions in civil relations. Together with other documents enacted in the same year such as the 2005 Commercial Law, the 2005 Intellectual Property Law, the Civil Code made a remarkable contribution towards removing legal barriers to the people's life. Especially, the 2015 Civil Code confirmed its role as the basic law in the private law system; it changed basically some legal regimes, especially the unification of contract laws and drastic reform in secured transactions. It contributed to the assurance of synchronicity of the system of legal normative documents in private law as a whole. However, at the inception of the new period in country's development, the current Civil Code revealed some limitations and inadequacies. Hence, the amended civil code - the 2015 Civil Code was adopted at the 10th Plenary Session, the 8th National Assembly on November 24, 2015. It comprises of 27 chapters and 689 articles. To guarantee the unification in the awareness, the 2015 Civil Code lays down eight basic principles of civil law which protect all individual's and legal entity's civil rights, acknowledged by the Constitution and the laws (Doan Thai Son, 2015).

\section{* Vietnam's civil law in the internationalization context}

Some legal experts believe that, in the current trend of the international trade and globalization, the legal integration among countries is essential. Vietnam's civil law has gradually been formed and improved in recent years by absorbing developed countries' progresses based on to the factual socioeconomic and cultural situation of the country. Especially, in current development of Vietnam civil law, special importance is being attached to the simplicity and straightforwardness serving not only for urban residents with high intellectual standard and less binding interpersonal relationships but also applicable to rural residents with their customs, habits and limited knowledge. In addition, lawmakers also pay much attention to the psychological, cultural characteristics of minority ethnic groups when absorbing international legislative progresses.

Our interview results show that in the context of the internationalization, Vietnam's civil law develops on the basis of protecting the democracy, people-closeness, and lofty mission to the society. Consequently, civil laws nowadays have become an effective means for the people to protect their rights and benefits in the daily civil relations. Generally speaking, civil law provisions have been developed for twofold purpose. On one hand, they orient the people's conducts, and on the other hand, they are means to correct mistakes, unintentionally or intentionally committed by individuals in daily civil relations committed by individuals in daily civil relations.

According to our interview results, in the context of internationalization, Vietnam's the current civil law is led by four main guiding principles. In more details, they include: (i) fully institutionalizing and strengthening measures to recognize, protect and assure better human rights, citizen rights in all spheres of civil life; (ii) revision of, and supplementation to provisions those show their limits in civil law enforcement practices; (iii) developing civil 
law into a foundation code of the system of laws governing the relationships established based on equality, freedom of will, independence of property; and (iv) inheriting and developing the regulations that still conform to civil law practices and the good traditional, cultural, ethic values of Vietnam.

As mentioned by the legal experts, in the integration and internationalization process, the current civil law has fulfilled well the three basic roles, namely: (i) creating an effective legal mechanism for recognizing, respecting, protecting and assuring individuals and legal persons' civil rights; (ii) reducing to a minimum public bodies' interventions in establishing, modifying, terminating civil relations; and (iii) creating favorable conditions for boosting production and business, effective exploitation of all social resources, ensuring the clearness and stability in civil exchange, contributing to the development of the socialist-oriented market economy and serving international integration. The focus of Vietnam's civil law at present is on some major issues such as: (i) ownership and other property rights; (ii) obligations and contracts; (iii) inheritance; and (iv) law applicable to civil relations involving foreign elements (Bui Thi Thanh Hang and Do Giang Nam, 2011).

However, Vietnam civil law in the internationalization context reveals some certain limitations. Typically, it is a land dispute between Mr. Doan Van Vuon and the authorities in Tien Lang district, Hai Phong province in 2012. This is one of the cases that attracted Vietnam's community as it is considered as the peak of land conflict. The case pointed out the inadequacies of Vietnam's civil law and the law enforcement at the local government level. Another typical civil case is the one of Huynh Thi Huyen Nhu, a fraud of VND 4 trillion in Vietinbank. Huyen Nhu took advantage of some individuals as brokers, the enterprise customers' representatives for making the illegal agreements. She possessed herself of five enterprises (including: Phuong Dong Company, Hung Yen Company, An Loc Company, SBBS Company, and Global Insurance Company).

The number of civil cases, in the recent year, increased in Vietnam. Remarkably, according to the Department of Ho Chi Minh City Civil Judgment, in the first six months of 2016, the Department received 63,000 civil cases with a total of over 43 billion VND. The total number of solved cases was over 22,400. It can be seen that the increasing number and complexity of civil cases require the development of Vietnam's civil law, especially in the globalization context.

In general, there are two major limitations of Vietnam's civil law, including: (1) Civil law provisions are inappropriate, complex and sometimes inconsistent with other relevant laws; and (2) The enforcement of civil law is not effective and transparent, especially at local government level. In the coming time, Vietnam should concentrate on solving these limitations for improving the law's role in the law system.

\section{$>$ Achievements of the 2015 Civil Code in the context of internationalization:}

In the direction of developing the Civil Code into the general law of the legal system, the 2015 Civil Code was developed on the basis of the former civil laws with the remarkable achievements. The objectives, the guiding principles in its development of the 2015 Civil Code have been greatly appreciated by experts. This Civil Code is marked by numerous important breakthroughs based on the implementation of the points of view, guidelines, policies of the Party and displays the spirit of the Constitution 2013, Vietnam's international commitments to respect, recognize, protect and assure human rights, citizen rights in the civil sphere, set up, improve socialist-oriented market economy institution, legal reform and international integration (Nguyen Huu The Trach, 2016). Specifically:

Firstly, the 2015 Civil Code fully plays its role as a basic law of the private law system of Vietnam. Specifically, the 2015 Civil Code lays down five basic principles of civil law, in which the principle of self-reconciliation is repealed, since this principle is already included in the principle of freedom, self-commitment and self-agreement. This novelty totally conforms to the orientation towards developing the 2015 Civil Code at a high level of generality. Especially, in the 2015 Civil Code, there is a change of awareness in the legislative thought. This is displayed in the expansion of types of law resources in applicable priority order from Article 4 to Article 6 of the 2015 Civil Code. It is noteworthy that as set out in Art.6.2 of the 2015 Civil Code when the similar principle provided for in Art. 6.1 is not applicable, civil laws basic principles stipulated in Art.3, judicial precedents and equity shall be applied.

Secondly, the 2015 Civil Code has been supplemented with general principles to establish, exercise and protect civil rights. Accordingly, individuals, legal persons exercise their civil rights by their will on the basis of complying with the basic principles of civil law and not exceeding the limits of the civil rights as specified in this Code. In addition, the provision "The court must not deny claims for civil case or matter resolution on the ground that there has been no applicable legal provision" (Art. 14 of the 2015 Civil Code) enables the subjects entitled to proceed claim to be fully eligible to protect their legitimate rights and benefits before the court. This is considered by experts to be a new provision as a breakthrough, since this provision helps protect in a timelier 
and thoroughgoingly manner human rights, citizen rights in the civil sphere.

Thirdly, the 2015 Civil Code concretizes all personality rights of individuals in order to define the subject status of individuals in the civil rights as specified in the Constitution and international conventions to which Vietnam is a member. It is noteworthy that the issue of redefining gender was recorded in civil law. According to Art. 37 of the 2015 Civil Code, gender identification can be affected under the provisions of the law. Individuals who have changed their gender have the rights and obligations to register the changes in their household registration in accordance with household laws; have the personal rights applicable to the gender changed under this Code and other relevant laws. This enables the 2015 Civil Code to guarantee the conformity with the nation's good traditions, customs and the general international practices as well as to meet the needs of a proportion of citizens.

Fourthly, the subjects in civil law relations are more specific and clearer. The 2015 Civil Code still inherits the 2005 Civil Code in governing scope and subjects. According to Art. 1 of the 2015 Civil Code, the subjects of civil law relations include individuals and legal persons. Household, collectives or other type of organization those are not seen as legal entities shall participate into civil legal relations via its individual representatives. This new point helps solve the problems in many recent years concerning the participation in civil relations of family households, cooperative groups, organizations without legal person status in the dispute resolution.

Fifthly, the provisions of the 2015 Civil Code on property and ownership are clearer and more sufficient. Art. 105 of the 2015 Civil Code has been supplemented with some provisions on property which include immovable property and movable property; property can be objects, monies, negotiable instruments, property rights over the subject of intellectual and other property rights. Compared with the 2005 Civil Code, the 2015 Civil Code provides more sufficiently about the time for establishing the ownership and other in rem rights. Besides, the 2015 Civil Code stipulates additionally the time for establishing other ownership right over property.

Sixthly, the 2015 Civil Code aims at stabilizing the civil relations. The 2015 Civil Code stipulates that when parties have met some certain provisions provided for under the law, the transaction, even if error in formality appears, its legal validity are still be recognized by the court and this serves as foundation for the establishment of the parties' rights and obligations. As assessed by experts, this is a flexible change in the criteria for assessment of civil transaction validity compared with the 2005 Civil Code. On account of that, the 2015 Civil Code contributes to defending ultimately the legitimate rights and benefits of the parties who have the will to voluntarily exercise all their obligations involved in the transactions. With regard to bona fide third party protection, compared with the provisions of the 2005 Civil Code, the 2015 Civil Code protects better the legitimate rights and benefits of bona fide parties in civil transactions (Art. 133.2).

Seventhly, the 2015 Civil Code attaches special importance to civil liabilities due to the failure to fulfill civil liabilities through a series of regulations so as to guarantee safety, clearness in civil relations as well as in civil case resolution.

\section{Some limits of the 2015 Civil Code in the context of internationalization:}

On the whole, Vietnam's current civil law in the context of internationalization is greatly appreciated by experts for its aim at better protection of citizens' legitimate rights and benefits in society, in compliance with principle of respecting the freedom of agreement by the parties in civil transactions. However, our interview results still show some limits of the 2015 Civil Code as follows:

According to civil law experts, in the 2015 Civil Code and specialized laws there still remain some inadequacies, particularly the application of ceiling interest rate. Art. 468 of the 2015 Civil Code the excludes the application of loan ceiling interest rate of $20 \%$ in circumstances where other relevant laws stipulate otherwise. Meanwhile, according to Art. 12 of the Law on State Bank 2010 and clauses 2, 3, Art. 91 of the Law on Credit Organizations 2010, under normal conditions, interest rates in banking operations will be decided by negotiation mechanism, without ceiling interest rate. It is obvious that the 2015 Civil Code excludes the loan ceiling interest rate of $20 \%$ per year from lending activities of credit institutions, whereas legislation on credit and banking permits the parties to credit relationships to agreement between themselves.

Interview results show that in assurance of the performance of obligations, the 2015 Civil Code still cannot solve the biggest problem, i.e. it fails to provide a uniform understanding about asset mortgage, pledge to secure the fulfillment of obligations by others. For the time being, many individuals, legal persons establish measures of asset mortgage, pledge to secure their fulfillment of the obligations by others. Accordingly, some credit institutions agree to establish this type of secured transaction while other do not. In the course of dispute resolution at the court sector, there also exist two points of view: (i) accepting secured transactions in forms of mortgage or pledge to secure another' civil obligation; and (ii) not accepting secured transactions in forms of 
mortgage or pledge, but accepting the measure of guarantee. Meanwhile, the Decree No. 11/2012/ND-CP on the amendment and supplements to some provisions of the Decree No. 163/2006/ND-CP did not provide any provisions detailing the fact that parties have the right to establish asset mortgage, pledge measures as security for the fulfillment of obligations by others. As a result, individuals, legal persons have to encounter legal difficulties and risks in conclusion and enforcement of asset mortgage or pledge contracts to guarantee the fulfillment of obligations by others.

In addition, interview results also reveal that as some provisions on adjacent real estates in the 2015 Civil Code do not actually conform to the reality, thereby creating a lot of problems in their application. Specifically, Article 271 stipulates that house owners can only fix doors and windows looking to the adjoining houses, opposite houses and common path in accordance with provisions of legislation on construction. Meanwhile, the current Construction Law does not touch on this issue. Further, the 2015 Civil Code does not stipulate clearly the compensation and resolution measures in case owners of adjoining properties do not allow house owners, land users to create accesses, water supply and drainage systems...in their land.

\section{* Analysis of Vietnam's civil law development trends in coming time in the context of internationalization}

As observed by the legal experts, in the context of the globalization and internationalization, the domain of private law, including civil law must always be updated and renovated to be suitable to the changes in civil law relations. According to interview results, Vietnam's civil law development trends in coming time in the context that the internationalization are still in line with the general tendency of the civil law systems of the countries in the region and all over the world. Specifically, Vietnam's civil law will develop on the basis of combining the national factor, international factor, and self-development factor. Vietnam's civil law system is changing and updated to meet the need for co-operation in the legal domain in the tendency towards stability, inheritance and self-development of the law under the influence of economic, political, social, ideological, geographical, and anthropological factors. This combination helps Vietnam civil law to be stable and find common grounds in the approach to international civil law system (Ngo Huy Cuong, 2000).

The interview results above highlight their remarkable achievements of the current Vietnam's civil law system. Nevertheless, the experts are still of the opinion that amending and supplementing to further improve the civil law system is necessary under the conditions of globalization at present. To do this, firstly Vietnam's the Civil Code should be people friendly as reflected in its legal language and writing way, so that people can more easily access and apply it in civil law relations. About the content, the Civil Code must perform well the mission of recognizing and respecting the most basic principles of the civil life. In addition to that, the issues of subjects, properties, contracts, inheritance, and torts must reflect the wishes of every individual for subject's freedom, freedom to contract principle, to protection of the absoluteness of private ownership, freedom to dispose inheritance estate, and principle of liability at fault.

In some experts' opinion, the content of Vietnam's civil law develops as a supportive institution that offers optimal legal solution for the people to promote civil relations in society. In addition, Vietnam's civil law shall be based on the principle of protection of the absoluteness of private ownership, on a public and transparent legal system on property in order to help the people to make the best use of the material property and the legal and monetary values of property. As to the system of contract enforcement, this system should be set up and improved on the principle of freedom to contract in order to meet well the expectations of the contractual subjects by minimizing transaction costs in accessing, negotiating, and executing contracts. As to the legal system of compensations for damages, legislators should pay more attention in order to maintain stable civil order in accordance with principle of liability at fault.

In addition, according to the interview results, civil law will still be made and developed in coming time, based on legal culture, in order to reflect the country's legal traditions and to guarantee effective enforcement in Vietnam. The Civil Code is expected to develop on the typical foundation, personality and spirit, principles of family organization, and living custom of the Vietnamese nation. The experts believe that the development trends of Vietnam's civil law will reflect the community generally accepted living standards and norms. In spite of the fact that individuals have the freedom of ownership, freedom to contract, freedom to dispose the inheritance estate ..., such freedoms are still restricted by the social ethics that the community is pursuing.

Therefore, in the coming time, especially in the context of globalization, civil law tends to attach more importance to establishing its values in the social life, to become a statutory declaration to reflect the civil life and development orientation of the country. To do this, according to experts, Vietnam should positively carry out open and wide discussion about the Civil Code's policies. The civil law development process should be 
recognized as an opportunity to raise the people's voice about the living order they are wishing.

\section{Recommendations to Improve Vietnam Civil Law in the Context of Internationalization}

From the results of theoretical and practical research on globalization and the development trends of Vietnam's civil law, we make some proposals to improve Vietnam's civil law in the context of internationalization, specifically:

Firstly, the legislators should strengthen the basic role of civil law in the relationship with specified laws so as to minimize the conflicts between civil law and specified laws and to facilitate individuals, legal persons and functional executive agencies to apply provisions in practice more easily. In the coming time, legislators and functional authorities should reviews the deficiencies between the Civil Code and the relevant specified codes in order to enhance the efficiency of civil law enforcement.

Secondly, the legislators should propose solutions to the issue of application of the current ceiling interest rate in order to overcome the conflicts between civil law and specified laws. Specifically, specified laws in coming time to come should lay down more specific and clearer provisions on the application of this interest rate. Legislative bodies may delete the phrase "in accordance with the provisions of the law" in clause 2, Article 91 of the Law on Credit Institutions 2010 to be in line with the provisions of the 2015 Civil Code. At the same time, such State bodies as Supreme People's Court, the State Bank of Vietnam...should issue legal explanatory documents and directory circulars for credit institutions and enterprises to follow. In the future, the Civil Code will still need to be amended in the interest rate related content on the basis of respecting the principles of negotiation by individuals and legal persons.

Thirdly, the legislators should lay down specific provisions on individual's and legal person's normal property rights in civil relations. At the same time, legislators should give specific directions on the properties to be formed in the future, including the properties that have not been formed yet and the properties that have been formed but the subjects have established their ownership thereof after the time of conclusion of the transactions. At the same time, legislators should also guide bodies in implementation of registration of notarized secured measure. When the future obligations set out in clause 2, Article 294 of the 2015 Civil Code are formed, the parties to the transaction do not have to re-conclude the secured contracts, to notarize or certify the secured contract or register secured measure in respect to such obligations.

Fourthly, the legislators should attach special importance to improve the issue of adjacent real estate in civil law. In the market economy in the context of internationalization, over a specific property, there may be some owners whose rights to possession of it differs that requires to be defined clearly and specifically by civil law. In its role as a basic law of the private law system, in the coming time, the Civil Code should have to settle this question in order to lay down legal grounds for the provisions of specified laws to rectify asset relations in the transfer process.

Fifthly, the authorities should timely review the specific civil relations that should be rectified in the relevant laws. Besides, competent bodies should attach importance to revise, supplement and enact new documents in the specialized management sphere so as to ensure the unity in improving and applying civil law.

\section{Concluding Remarks}

On the basis of the interview results on 12 civil law experts, the article gives some assessments of Vietnam's civil law's the development trends in the context of the internationalization. The 2015 Civil Code has made a lot of achievements with the aim of developing the Civil Code into a general law of the legal system governing civil relations, serving international integration, stabilizing the legal environment for socioeconomic development. However, according to the interview results, Vietnam's the current civil law still reveals some limits among those the inadequacies between civil law and specified laws are the biggest limitations that need to be promptly overcome to facilitate individuals, legal persons, and competent executive authorities to apply the provisions more easily in practice.

The article also focuses on analyzing the development trends of Vietnam's civil law in coming time in the context of internationalization. According to the results of interviewing civil law experts, the development trends of Vietnam's civil law in coming time in the context of internationalization are generally be in line with the general trend of civil law systems of the countries in the region and all over the world. Specifically, Vietnam's civil law should develop on the basis of combining the national factor, international factor, and self-development. Vietnam's civil legal system is changing and updated to meet the need for co-operation in the legal domain in the tendency towards stability, succession and self-development of the law under the influence of economic, political, social, ideological, geographical, and anthropological factors. This combination helps Vietnam's civil law to be 
stable and find common grounds in its approach to the international civil law system.

The research proposes some recommendations for improving Vietnam's civil law. In the coming time, Vietnam legislators should strengthen the basic role of civil law in the relationship with specified laws so as to minimize the conflicts between civil law and specified laws. Besides, legislators should propose solutions to the issue of application of the current ceiling interest rate; the normal property rights of individuals and legal persons in civil relations; and adjacent real estate so as to improve civil law in the context of internationalization. In addition, Vietnam should also attach special importance to revise, supplement and enact new documents in the specialized management sphere so as to ensure the unity in improving and applying the civil law.

\section{References}

Arpita, C. (2016, November). Globalization and monetary policy comovement: International evidence. Journal of International Money and Finance, 68, 181-202. http://dx.doi.org/10.1016/j.jimonfin.2016.06.019

Bộ Luật Dân sự (1995). Quốc hội nước Cộng hoà xã hội chủ nghĩa Việt Nam khoá IX, kỳ họp thứ 8, thông qua ngày 28 tháng 10 năm 1995.

Bộ Luật Dân sự (2005). Quốc hội nước Cộng hoà xã hội chủ nghĩa Việt Nam khoá XI, kỳ họp thứ 7 thông qua ngày 14 tháng 6 năm 2005.

Bộ Luật Dân sự (2015). Quốc hội nước Cộng hòa xã hội chủ nghĩa Việt Nam khóa XIII, kỳ họp thứ 10 thông qua ngày 24 tháng 11 năm 2015.

Buchler, A., \& Muller-Chen, M. (2012). Private Law: National - Global-Comparative. Intersentia Publishers.

Bùi Thị Thanh Hằng, Đỗ Giang Nam. (2011). Sức sống của LDS Việt Nam từ góc nhìn so sánh với LDS Pháp, Đức, Hà Lan. Tạp chí Nghiên cứu pháp luật tháng 8/2011.

Caenegem Van, R. C. (1996). An Historical Introduction to Private Law. Cambridge University Press. pp. 1,12. http://dx.doi.org/10.1017/CBO9780511622038

Chen, J. F. (2008). Chinese Law: Context and Transformation. Martinus Nijhoff Publishers.

Đoàn Thái Sơn. (2015). Những nội dung cơ bản của bộ luật dân sự năm 2015. Trang Cổng TTĐT Ngân hàng nhà nước Việt Nam.

Faunce, T. A. (2012). Encyclopedia of Applied Ethics (2nd ed.). Academic Press.

Hà Hùng Cường. (2016). Bộ luật Dân sự năm 2015 hướng tới sự phát triển nhanh, bền vũng theo thể chế kinh tế thị truờng định hướng XHCN. Báo nhân dân điện tử ngày 25/01/2016.

Hoàng Thư. (2014). Sửa đổi Bộ luật Dân sự: Gỡ “điểm nghẽn”, tạo đà cho doanh nghiệp phát triển. Báo Pháp luật Việt Nam 2014.

Murray, R. (2015). The importance of reforming civil law in formerly socialist legal systems. International Comparative Jurisprudence, 1(1), 24-32. http://dx.doi.org/10.1016/j.icj.2015.10.007

Nghị quyết số 48-NQ/TW ngày 24 tháng 5 năm 2005 của Bộ Chính trị về Chiến lược xây dựng và hoàn thiện hệ thống pháp luật Việt Nam đến năm 2010, định hướng 2020.

Ngô Huy Cương. (2000). Cải cách pháp luật ở Việt Nam: Suy nghĩ về sự cần thiết và một số định hướng cơ bản. Nghiên cứu Lập pháp số 8/2000.

Nguyễn Hữu Thế Trạch. (2016). Những điểm tiến bộ của Bộ luật Dân sự 2015. Vietnamnet ngày 09/11/2016.

Nguyễn Minh Tuấn. (2007). Tập bài giảng Lịch sử nhà nuớc và pháp luật thế giới. Nhà xuất bản chính trị Quốc gia, Hà Nội, năm 2007.

Nguyễn Ngọc Điện. (2016). Giáo trình Luật Dân sụ Việt Nam tập 1, Nhà xuất bản Đại học quốc gia thành phố Hồ Chí Minh 2016.

Nguyễn Quyết Thắng. (2002). Lược khảo Hoàng Việt Luật lệ. NXB Văn hóa thông tin 2002.

Pim, M., Dreher, A., \& Gaston, N. (2010). Globalisation, the global village and the civil society. Futures, 42(6), 574-582.

Phan Huy Chú. (1961). Lịch Triều Hiến Chuoong Loại Chí. Nhà in Bảo - Vinh.

Viện sử học Việt Nam. (1991). Quốc Triều Hình luật (Luật hình triều Lê). Nhà xuất bản Tư pháp.

Wang, C., \& Madson, N. H. (2013). Inside China’s Legal System (1st ed.). Chandos Publishing.

Wright James, D. (2015). International Encyclopedia of the Social \& Behavioral Sciences (2nd ed.). Elsevier. 


\section{Copyrights}

Copyright for this article is retained by the author(s), with first publication rights granted to the journal.

This is an open-access article distributed under the terms and conditions of the Creative Commons Attribution license (http://creativecommons.org/licenses/by/4.0/). 